\title{
The Hajj and Europe in the Pre-Colonial and Colonial Age
}

The Hajj, or the Muslim Pilgrimage to the Holy Places in Mecca and Medina, is not merely a religious undertaking of devotion for Muslims; it is a global annual event that included political, social, economic, and intellectual aspects throughout world history. The study of Hajj history in the pre-modern and modern eras unravel important mundane human ties and networks of mobility that go beyond its primary religious meanings for millions of Muslim believers around the globe. In other words, throughout history the Hajj traffic routes and itineraries regularly created new religious, political, social, and cultural contact zones between Muslim regions on the one hand, and with the geographical boundaries of other parts of the world on the other. Since medieval Islamic history, the Hajj had "accelerated sea trade as thousands of pilgrims and merchant-pilgrims made their way to Mecca and Medina by sea, stopping at coastal towns where they often traded goods."

European connections to the Hajj have a lengthy history of centuries before the influx of Muslim migration to the West after World War II. During the colonial age in particular, European and Ottoman empires brought the Hajj under surveillance primarily for political reasons, for economic interests in the control of steamships and for the fear of the growth of pan-Islamic networks. Another important motive for the European scrutiny of Hajj was their anxiety for the spread of epidemic diseases in their colonies after the pilgrims' return.

The present volume focuses on the political perceptions of the Hajj, its global religious appeal to Muslims, and the European struggle for influence and supremacy in the Muslim world in the age of pre-colonial and colonial empires. By the term "empire," we follow in this volume Jonathan Hart's particular reference to "those western European nations who, beginning with Portugal, began in the fourteenth and fifteenth centuries to expand offshore and later overseas." 2 In the late fifteenth century and early sixteenth century there was

1 Dionisius A. Agius, Classic Ships of Islam From Mesopotamia to the Indian Ocean (Leiden: Brill, 2008), 65 .

2 Jonathan Hart, Comparing Empires: European Colonialism from Portuguese Expansion to the Spanish-American War (Basingstoke: Palgrave Macmillan, 2003), 2.

(C) UMAR RYAD, 2017 | DOI: 10.1163/9789004323353_002

This is an open access article distributed under the terms of the CC-BY-NC License. 
a pivotal change in seafaring through which western Europeans played important roles in politics, trade, and culture. ${ }^{3}$ Looking at this age of empires through the lens of the Hajj puts it into a different perspective by focusing on the question of how increasing European dominance of the globe in pre-colonial and colonial times had been entangled with Muslim religious action, mobility, and agency. The study of Europe's connections with the Hajj therefore tests the hypothesis of how the concept of agency is not limited to isolated parts of the globe. By adopting the "tools of empires," ${ }^{4}$ the Hajj, which by nature is a global activity, would become part of global and trans-cultural history.

With this background in mind, the volume is a collection of papers, most of which were read during the "Europe and Hajj in the Age of Empires: Muslim Pilgrimage prior to the Influx of Muslim Migration in the West" conference, held at the University of Leiden (13-14 May 2013) in collaboration with King Abdul-Aziz Foundation in Riyadh. A group of scholars were invited in order to investigate European connections with the Hajj on various levels. The read papers reflected on how much first-hand primary sources can tell us about European political and economic perceptions of the Hajj. How did the international character of the Hajj as a Muslim sacred ritual influence European policies in their struggle for supremacy over the Muslim world? How did Muslim subjects under European colonial rule experience the logistic, economic, religious, and spiritual aspects of the Hajj?

In early-modern and modern history, the Hajj became connected to the long European tradition of seafaring in the Western Indian Ocean firstly by the Portuguese in the 16th century, the Dutch during the 16th to 18th centuries, and the English presence during the 19th to late mid-2oth century. ${ }^{5}$ It is true that the Portuguese introduced a new kind of armed trading in the waters of the Indian Ocean. This period was "an age of contained conflict" in India and the Indian Ocean. ${ }^{6}$ In the early modern period in particular, Muslim ships carrying pilgrims were threatened by the Portuguese. In 1502, for example, a

3 Hart, Comparing Empires, 3.

4 Daniel Headrick, The Tools of Empire: Technology and European Imperialism in the Nineteenth Century (New York: Oxford University Press, 1981); as quoted in James L. Gelvin and Nile Green (eds.), Global Muslims in the Age of Steam and Print (Berkeley: University of California Press, 2013), 3 .

5 Agius, Classic Ships of Islam, 4. See also, Tamson Pietsch, "A British Sea: Making Sense of Global Space in the Late Nineteenth Century," Journal of Global History 5/3 (2010): 423-424. Eric Tagliacozzo, "Navigating Communities: Distance, Place, and Race in Maritime Southeast Asia," Asian Ethnicity 10/2 (2009): 114.

6 Bose, A Hundred Horizons, 19. 
large ship was captured by the Portuguese, which had 200 crew and numerous pilgrims aboard. Muslim ships carried warriors in order to resist Portuguese arracks. ${ }^{7}$ The arrival of the Portuguese in surrounding seawaters put the Hajj at risk, since they were keen on opposing Islam and monopolizing the spice trade. From the start, they attempted to patrol the Red Sea entrance and block the "pilgrimage to the accursed house of Mecca." ${ }^{8}$ The Ottomans had difficulties dealing with the increasing grievances of the Muslim believers who were unable to "go to the house of Mecca, to take their alms and fulfill their pilgrimage, because the Christians take them at sea, and also within the Red Sea, and they kill and rob them and the least that they do is to capture them." 9

Other European mercantile entrepreneurs started to compete with the Portuguese in the East. In later centuries, such conditions of piracy and robbery relatively started to change. In the colonial age, despite the fact that Mecca and Medina were officially under Ottoman rule, the Hajj was put under the surveillance of European imperialist powers. Therefore it became a significant arena for politics and expansion. Under colonial rules, however, the Hajj bore a wider global imprint and was enhanced by European technology such as the steamship. A journey that used to take months or even years by land or sea was now shortened, which had consequently increased the number of pilgrims and their logistics. ${ }^{10}$ European competition in the expansion of maritime supremacy demanded the surveillance of pilgrims and the spread of epidemic diseases, such as cholera and plague. ${ }^{11}$ In that sense, the Hajj had acquired sev-

7 M.N. Pearson, Pious passengers: The Hajj in earlier Times (London: Hurst \& Company, 1994), 57. See also, David Arnold, "The Indian Ocean as a Disease Zone, 1500-1950," South Asia 14: (1991): 1-21; and Takashi Oishi, "Friction and Rivalry over Pious Mobility: British Colonial Management of the Hajj and Reaction to it by Indian Muslims, 1870-1920," in Hidemitsu Kuroki, ed., The Influence of Human Mobility in Muslim Societies (London: Kegan Paul, 2003).

8 Pearson, Pious passengers, 89.

9 As quoted in Pearson, Pious passengers, 93. For more see, Suraiya Faroqhi, Pilgrims and sultans: the Hajj under the Ottomans, 1517-1683 (London: Tauris, 1994).

10 See, John Slight, "The Hajj and the Raj: From Thomas Cook to Bombay's Protector of Pilgrims," in V. Porter and L. Saif (eds.), Hajj: Collected Essays (London: British Museum Research Publications, 2013), 115-121.

11 Michael Christopher Low, "Empire of the Hajj: Pilgrims, Plagues, and Pan-Islam under British Surveillance, 1865-1926," Unpublished ma Thesis, College of Arts and Sciences, Georgia State University, 2007, available at (http://digitalarchive.gsu.edu/history_theses/ 22). See also Michael Christopher Low, "Empire and the Hajj: Pilgrims, Plagues, and PanIslam under British Surveillance, 1865-1908," IJMES 40/2 (2008): 269-290. 
eral aspects, such as modern transport, hygiene, espionage, exoticism, political colonial interests and trade, and diplomacy.

\section{European Colonial Control of the Hajj and Public Health}

On another level, Mecca and Medina were, and still are, significant centres of religious education for Muslim students belonging to different backgrounds, who come to acquire normative and traditional religious knowledge and carry it back to their places of origin. In the colonial period, the Hajj and these religious educational centres created transnational, anti-colonial, pan-Islamic networks that were sources of fear for colonial officials. Due to the transmission of subversive politics to the colonies, European officials became suspicious of any underlying allegiances of the Hajj that could be the binding trigger for international anti-colonial sentiments and uprisings. In the early twentieth century, for example, the Dutch colonial government cooperated with Dutchowned shipping companies in order to control Hajj maritime networks linking the Netherlands East Indies and the Middle East. ${ }^{12}$

Besides, Jeddah as a port city served as the nodal point of exchange and interaction not only for the Hajj (as the main entry point for pilgrims) but also for trade as well as the European consulates. Sources are scarce regarding the beginning of European political or commercial agency in Jeddah. It is clear that Jeddah was chosen for the establishment of the European consulates for its strategic position that facilitated European political penetration of foreign powers in the region. By 1832, for example, an Armenian of Baghdadi origin, Maalim Yusof, was appointed as East India Company (EIC) agent in Jeddah. However, the French consular agency (later variously consulate and vice-consulate) was officially founded in 1839 . The Dutch, who had long trade relations in the regions, established their consulate in 1869 or 1872 when they became concerned with the large numbers of Southeast Asian pilgrims. In January 1876, the Swedish King appointed a consul for Sweden and Norway with the authorization to collect certain taxes from Swedish merchants in accor-

12 Kris Alexanderson, “'A Dark State of Affairs': Hajj Networks, Pan-Islamism, and Dutch Colonial Surveillance during the Interwar Period", Journal of Social History 7/4 (2014): 1021-1041. Eric Tagliacozzo, "The Skeptic's Eye: Snouck Hurgronje and the Politics of Pilgrimage from the Indies," in Southeast Asia and the Middle East: Islam, Movement, and the Longue Durée, ed. Eric Tagliacozzo (Stanford: Nus Press, 2009), 135-155. Cf. Michael Francis Laffan, Islamic Nationhood and Colonial Indonesia: The Umma Below the Winds (London: Routledge Curzon, 2003). 
dance with consular regulations. Austria opened its consulate in 1880 , succeeded by the Russians who dealt with rising numbers of Central Asian pilgrims in $1891 .^{13}$ In her well-documented article, Ulrike Freitag argues that European consuls in Jeddah had less relative power and local influence than other European consulates elsewhere in the Ottoman Empire. A strong international balance of power could not be easily established in Jeddah "due to the special role of Jeddah for the Islamic legitimation of the empire, as well as the local awareness of its location in the vicinity of the holiest city of Islam, both of which in turn prevented the settlement of significant Christian communities."14 In general, a few dozen non-Muslims resided in Jeddah but did not represent a coherent community. European consuls were present in Jeddah for the sake of pilgrims from the colonies and merchants from the European empires who were "not normally perceived as allies." ${ }^{5}$

In the nineteenth century, European nations had already become highly concerned about the spread of diseases to European colonies, and more significantly within European borders, as a result of the crowd of the annual gathering of the Hajj. To keep European authority intact, colonial administrations exploited their calls for international health and safety standards for the Hajj not only as a medical strategy to prevent the spread of epidemic diseases but also as a surveillance tool aimed at stopping the spread of political unrest in the colonies. Besides ship monopolies, health regulations and "sanitary politics" surrounding the Hajj created a power situation that required intellectual knowledge and promoted cultural and technological hegemony of the empires. Despite the fact that many countries were involved in the sanitary regulations of the Hajj, the British and the Dutch played the largest role in administering this field in the Arabian Peninsula due to the high number of colonial subjects traveling to Hajj. ${ }^{16}$ Therefore, due to any potential health danger that might be

13 Ulrike Freitag, "Helpless Representatives of the Great Powers? Western Consuls in Jeddah, 1830s to 1914," The Journal of Imperial and Commonwealth History 40:3 (2012): 359-36o. Cf. Elena I. Campbell, “The 'Pilgrim Question': Regulating the Hajj in Late Imperial Russia,” Canadian Slavonic Papers 56:3-4 (2014): 239-268; Eileen Kane, Russian Hajj: Empire and the Pilgrimage to Mecca (Ithaca: Cornell University Press, 2015).

14 Freitag, "Helpless Representatives," 357.

15 Freitag, "Helpless Representatives," 362.

16 See Eric Tagliacozzo, The Longest Journey: Southeast Asians and the Pilgrimage to Mecca (Oxford: Oxford University Press, 2013); John Slight, The British Empire and the Hajj, 18651956 (Cambridge, MA: Harvard University Press, 2015); John Slight, "British Imperial rule and the Hajj," in D. Motadel (ed.), Islam and the European Empires (Oxford: The Past and Present Series, Oxford University Press, 2014), 53-72. 
caused by the Hajj, the Ottoman Empire was sometimes viewed in the European press as "a gateway for contamination" in Europe itself. ${ }^{17}$ As a matter of fact, cholera was found in Arabia in 1821 for the first time. Ten years later it was in the Hijāz; and since then it became a mainstay on the pilgrimage routes. In 1831 the epidemic killed twenty thousand people in the Hijāz, followed by other subsequent epidemics in the region of the holy cities in $1841,1847,1851,185^{-}$ 1857 , and 1859 . Cholera entered Europe around the same period, most likely not through the Middle East, but rather over the Eurasian steppe, from Russia and eventually into Germany. Nevertheless, the 1865 epidemic in the Hijāz was so powerful that its damage reached Europe and the western parts of the United States. ${ }^{18}$

As a matter of fact, international surveillance of the public health ramifications of the Hajj was put forward for investigation at the works of the ${ }^{1851}$ Paris International Sanitary Conference for the first time. With this conference, France claimed herself to be "at the forefront of the nineteenth century's international drive to come up with regulatory codes applicable to Mecca-bound ships and pilgrims alike."19 In some uncontrollable cases in French African regions, central and local colonial authorities sometimes tried to "justify their decisions in the face of public opinion when the prohibition of Hajj seemed to be the only option." ${ }^{20}$

Quarantine stations were set up as preventive rubrics to securitize epidemics among pilgrims on the one hand and to control their socio-political actions on the other. For example, the Kamaran quarantine station in the Red Sea, established in 1881 as a site for surveillance over pilgrims, their diseases, and politics in the region, enabled the British and Dutch colonial governments to register lists of passengers aboard pilgrim ships. In Kamaran the British were even said to have established an equipped radio station and an excellent landing area that was regularly visited by British war planes. Therefore, the

17 Kris Alexanderson, "Fluid Mobility: Global Maritime Networks and the Dutch Empire, 1918-1942," PhD thesis (Graduate School-New Brunswick Rutgers, The State University of New Jersey, 2011), 97-99. Cornelia Essner, "Cholera der Mekkapilger und internationale Sanitatspolitik in Agypten (1866-1938)," Die Welt des Islams 32/1 (1992): 41-82.

18 Eric Tagliacozzo, "Hajj in the Time of Cholera: Pilgrim Ships and Contagion from Southeast Asia to the Red Sea," in James L. Gelvin and Nile Green (eds.), Global Muslims, 105 .

19 Marième Anna Diawara, "Islam and public health: French management of the Hajj from colonial Senegal and Muslim responses beginning in 1895," (PhD thesis, Michigan State University, 2012), 271.

20 Diawara, "Islam and public health," 272. 
Dutch became alarmed that Britain was using the site as a spy station. ${ }^{21}$ In sum, by the late nineteenth century European colonial powers generally became anxious about a "twin infection" of the Hajj, namely Muslim anti-colonial ideological infection and bacteriological infection. ${ }^{22}$

Nevertheless, British India provided the largest number of pilgrims in the late nineteenth century. Likewise, the British policy of Hajj was similarly shaped by political calculations and public health concerns. On the surface, the British were not keen on interfering in Muslim religious affairs, especially after the famous promise by the Queen in the wake of the massive uprising across much of India in 1857-1858. Saurabh Mishra argues that by the turn of the twentieth century such British political calculations started to change into increased surveillance of pilgrims due to the perceived fear of jihad and fanaticism. As European demands for regulating the Hajj out of fears for disease spreading to their borders increased, medical concerns became the most important aspect of British international policy towards the Hajj, which resulted in what Mishra calls a European "Medicalizing Mecca." 23

\section{Europeans in Mecca}

On the cultural level, the creation of a Hajj public knowledge was taking place in Europe in the background of such political and medical discourses. Indigenous Muslims in Central and Eastern Europe, a few Muslim emigrants (especially in Great Britain, France and somehow in Germany), and European converts to Islam in other parts of Europe were making their way to the Hajj and left behind interesting accounts, such as diaries, published and unpublished travelogues, press items in European newspapers, etc. European and non-European national and private archives enlist fascinating political, medical, religious and social reports of such narratives. In the pre-modern and early modern age, Europeans, either converts to Islam or in disguise, entered Mecca. ${ }^{24}$ In the eighteenth and early nineteenth century, European encounters

\footnotetext{
21 Alexanderson, "Fluid Mobility," 104-105.

22 William Roff, "Sanitation and Security: The Imperial Powers and the Nineteenth Century Hajj," Arabian Studies 6 (1982): 143-160.

23 Saurabh Mishra, Pilgrimage, Politics, and Pestilence: The Haj from the Indian Subcontinent 1860-1920 (New Delhi: Oxford University Press, 2011).

24 Augustus Ralli, Christians at Mecca (London: William Heinemann, 1909). See also, John Slight, "Pilgrimage to Mecca by British converts to Islam in the interwar period," in R. Natvig and I. Flaskerud (eds.), Muslim Pilgrimage in Europe (Farnham: Ashgate, 2016). Mary
} 
with the Orient in general challenged western historical and religious understandings. However, European narratives of the Hajj should be read as colonial texts, which reflect a process of shift in European learning and culture that occurred in the context of interaction between East and West. ${ }^{25}$ One of the most remarkable figures who visited Mecca in the nineteenth century was the Dutch scholar of Islam Christiaan Snouck Hurgronje (1857-1936), whose contacts with Mecca and Arabia embodied both colonial and scholarly projects. The prime reason behind his mission in Arabia (1884-1885), after his conversion to Islam and circumcision, was to collect accurate information about the pan-Islamic ideas resonating among the Southeast-Asian community in Mecca. In addition, he was motivated by his scholarly interests in Mecca, its intellectual life and the Hajj. In Mecca he collected a huge amount of information and established a good network of Muslim friends. His writings formed the basis of scholarly western knowledge of Mecca and the Hajj in the nineteenth century and beyond. ${ }^{26}$

In recent years, many archive-based historical analyses have argued that many European converts entered Mecca in order to achieve specific political goals for their countries. In that sense, their roles are seen as part of the political and cultural conflict between Europe and Islam in the age of empires. It is true that in the colonial period the accounts of European pilgrims conveyed a sense of "passing" and "surpassing" due to their access to Western power

Jane Maxwell, "Journeys of faith and fortune: Christian travelers in the fifteenth and early sixteenth-century Dar al-Islam," (Unpublished PhD Thesis, Washington State University, 2004).

25 See Kathryn Ann Sampson, "The Romantic Literary Pilgrimage to the Orient: Byron, Scott, and Burton," (Unpublished PhD Thesis, The University of Texas at Austin, 1999).

26 Much has been written about him, see, P.S. van Koningsveld, Snouck Hurgronje alias Abdoel Ghaffar: enige historisch-kritische kanttekeningen (Leiden: Rijksuniversiteit, 1982); P.S. Koningsveld, Snouck Hurgronje en de Islam: Acht artikelen over leven en werk van een oriëntalist uit het koloniale tijdperk (Leiden: Rijksuniversiteit, 1988); Arnoud Vrolijk en Hans van de Velde, Christiaan Snouck Hurgronje (1857-1936): Oriëntalist (Leiden: Leiden University Library, 2007); C. Snouck Hurgronje, Mekka in the Latter Part of the 1gth Century: Daily Life, Customs and Learning, translated by J.H. Monahan with an introduction by Jan Just Witkam (Leiden: Brill, 2007); Michael Laffan, "Writing from the colonial margin. The letters of Aboe Bakar Djajadiningrat to Christiaan Snouck Hurgronje," Indonesia and the Malay World 31/91 (November 2003): 357-380; Eric Tagliacozzo, "The skeptic's eye: Snouck Hurgronje and the politics of pilgrimage from the Indies," in Southeast Asia and the Middle East: Islam, movement, and the longue durée (Stanford: Stanford University Press, 2009), $135^{-155}$. 
and knowledge. ${ }^{27}$ However, in some other cases reading their accounts of Hajj engagement reveals a certain complexity by which they attempted to constitute a means through which they would refashion their spiritual life standards. Such sources are significant in their representation of a new literary genre that shaped a European image of Muslim pilgrimage.

\section{The Contributions}

The present volume looks at the Hajj and its ties with Europe through a variety of windows. The contributions posit three major elements related to the Hajj as a Muslim universal undertaking and its enmeshed history of European precolonial and colonial powers. Firstly, some tackle the questions of how European links and struggles to control the Hajj and the movements of the pilgrims were part of broader European political objectives and competitions in colonial regions. By strengthening a "Hajj policy" in colonial administration, European powers tried to take hold of the political, shipping, and hygienic aspects of it by means of the creation of quarantine stations for the fear of epidemics. Secondly, some essays explore the linkage between early Islamic anti-colonial networks and the Hajj. In that regard, European imperial administrators and consuls in Muslim regions were deeply concerned with recording and monitoring the pilgrims. In order to counteract such perceived "negative" influences, Mecca and the Hajj were seen on the political agenda as a breeding ground for "religious fundamentalism." Thirdly, some chapters deal with the Hajj as an intercultural arena in Europe by focusing on a few examples of Europeans who travelled to Mecca and recorded the Hajj through European eyes in the colonial period. The chapters cover a wide range of perspectives including historical surveys, political reports, and individual European accounts of the Hajj related to Portugal, Great Britain, France, Germany, the Netherlands, Hungary, Poland, and Spanish Morocco. These different cases highlight the Hajj on a global scale by showing its socio-political and economic aspects, routes, means of transport, logistics, hygiene problems, and cultural production and dissemination of ideas and knowledge about the Hajj in Europe.

In that context, Mahmood Kooria starts off the discussion by focusing on the early sixteenth-century Portuguese/European encounters with the Hajj in the Indian Ocean. He argues that this Portuguese interference in the Hajj was

27 M. Herman Erman, "Roads to Mecca: Conversion narratives of European and Euro-American Muslims", The Muslim World 89 (1999): 82-83. 
provoked by multiple layers of economic, political, cultural, and religious interests. Despite Portuguese economic motivations that had no direct prerequisites to intercept the Hajj, a correlation between the "secular" and "religious," the Portuguese relationship with the Hajj was deeply rooted in a long-tradition of European encounters with the Muslim world in the pre-modern age which had significant religious undertones. The religious collision between "Christian" Europe and the "Muslim" world that intensified in the time of the Crusades continued to exist in the waters of the Indian Ocean. The chapter argues that the Portuguese had a special interest in the Hajj, and their attacks on pilgrimships could not be totally isolated from the emphasis on the contemporary developments in Europe, conflicts in the Indian Ocean, and the association of Catholic missions with Portuguese undertakings in Asia. By the turn of the sixteenth century various misconceptions about Mecca, the Hajj and the tomb of the Prophet Muhammad had prevailed in the West. By centering the analysis on a few examples of anti-Portuguese Muslim polemical treatises and poems in India, the chapter concludes that the ritualistic corpus of the Hajj had become a matter of hostile engagements during the early stages of European expansion.

In the realm of European competition for the monopoly of hajj-shipping and the control of sanitary regulations, Michael Christopher Low analyses the involvement of Thomas Cook \& Son in the Hajj in the late nineteenth century. The chapter demonstrates a dissonance between Cook's reputation for elite travel in the Orient and its role in the pilgrimage trade. In sharp contrast to such princely travels, the Hajj in this time was viewed as an anachronistic, even dangerous, mode of travel that was mostly characterized by the mass movement of the poor. The role of Thomas Cook reveals how British officials in India framed their reform of the pilgrimage-travel industry as a question of direct regulation of pilgrims versus indirect commercial intervention by reconfiguring the system of guides, brokers, and shippers in India and the Hijāz. The chapter attempts to identify the political and commercial forces that proved so resilient in thwarting British regulation of the Hajj for so many decades. The Thomas Cook Hajj project was the embodiment of indirect intervention by the British whose entrance into the pilgrimage-shipping industry immediately altered price structure, ticketing procedures, and flexible timetables.

Amid European political, medical, and economic interests in the Hajj, a new arena of knowledge about this Muslim religious practice was created in Europe. John Slight discusses British efforts to obtain, collate, and interpret information on the Hajj by officials working for the British Empire. On the basis of information recorded by the British Consulate in Jeddah, the chapter starts in 1870 , when Britain's engagement with the Hajj hugely expanded, and continues to 
the eve of the Second World War, which marks a caesura in the pilgrimage's history. The chapter demonstrates the change of British knowledge production on the Hajj over time, being a combination of wider concerns about the threat of epidemic disease and political turmoil in the Hijāz, primarily the shifts from Ottoman to Hashemite then Saudi control after the First World War. Slight argues that the outcome of hajj knowledge was not purely a European production, but represented a sense of entanglement between colonial officers and consuls and Muslim indigenous informants. The Muslim employees of the Jeddah British Consulate had played a vital role in the production of British knowledge related to the Hajj. These reports immensely contributed to the creation of "colonial knowledge" on the Hajj. Their representations of the Hajj and pilgrims mirrored - and shaped - the prejudices of their British employers.

Aldo D'Agostini points out that although French control of the Hajj in the nineteenth century was inspired in part by humanitarian worries about the spread of diseases, their interest in the Hajj was also influenced by myths and prejudices and in some cases was ascribed to "strong Islamophobia." The chapter argues that European administrators in French Algeria were anxious about the possibility that pilgrims were exposed to political propaganda which had made them more "fanatical" than before. This situation led to the French adoption of a policy of repression of the Hajj which also included proposals to completely ban it. By focusing on the political policy of Jules Cambon, a governor of Algeria in the period 1891-1896, towards the Hajj and the pilgrimage trip of Jules Gervais-Courtellemont, a French traveller and convert to Islam, D'Agostini argues that both types of knowledge certainly affected French policy towards the Hajj. Such debates on Islam in the French colonial administration and public opinion were therefore a prelude to the institutionalization of Islam in France in the later inter-war period, such as the establishment of the Great Mosque in Paris.

Gervais-Courtellemont entered Mecca as a European convert to Islam. Some other European narratives of the Hajj were sometimes a mixture of reality and imagination. Ulrike Freitag reflects upon the German adventurer Heinrich von Maltzan and his two volumes, My Pilgrimage to Mecca, published first in 1865 and ostensibly accounting for his voyage to the Holy City of Mecca in 1860. His detailed account is of a clearly Orientalist variety, with a keen interest in the more scandalous aspects of society and life in the Hijāz. By comparing his published travelogue with his diaries, which was made available by one of his descendants, Freitag suspects the historicity of the account, since the diary entries point to a stay in the Swiss Alps instead of the Hijāz. The chapter looks at textual evidence in other verifiable writings by von Maltzan, such as his account of visiting Jeddah and Aden in 1870 , so as to argue that von Maltzan 
played on notions of reality and dream, drug induced high, and pilgrimage induced salvation. In the following chapter Bogusław R. Zagórski analyses a similar genre of imagination about the Hajj, which emerged in the nineteenthcentury Polish-Lituanian Tatar tradition. It presents a legend of two mystical travels to the Holy Cities of Islam. The first one was written by a local holy man and countryside dweller who claimed, due to his exceptional piety, to possess a faculty of translocating his body to Mecca. The second is a nonfiction travel report by a certain Ignacy Żagiell (firstly published in 1884) that gained a certain notoriety and popularity in the history of Polish travel writing. By re-reading such works, the chapter underlines a Muslim Polish move from reality to a cherished dream and how the Hajj consequently found its way in to popular beliefs. The latter travel account belonging to a non-Muslim cultural environment in the same geographical area highlights how such works expose a Polish "orientalność" - "Orientality" that was probably typical of Eastern Europe in contrast to the Orientalist engagement with the Hajj in Western Europe.

By the turn of the twentieth century, and specifically in the interwar period, a new transcultural dimension emerged in world history, with the Hajj playing an important role therein. After World War I, we can observe a "multiplication of new borders and the variety of transgressing institutions, concepts, actors, men and women inventing themselves as global subjects." ${ }^{28}$ Highlighting the Hajj and Europe from this transcultural historical perspective puts forward a new research tool that will therefore "explicate the history of transnational secular and religious communities." 29 Chapters seven and eight try to serve this goal by focusing on the structure and narratives of the accounts of two European converts to Islam who travelled to the Hajj in 1935 but probably never knew each other. Common narratives are mentioned in their travels, but in their special cases the Hajj was seen through the eyes of a Dutchman and a Hungarian. Umar Ryad discusses the pilgrimage of Dr. P.H. (or Mohammed Abdul-Ali) van der Hoog (1888-1957), a Dutch bacteriologist whose name is much connected nowadays to a famous cosmetic company in The Netherlands (http://www.drvanderhoog.nl/). Van der Hoog's role as a medical doctor in Jeddah in the late 1920 s was colossal in his conversion to Islam, visit to Mecca, and performance of the Hajj. As a vivid account of a European Hajj, Van der Hoog never identified himself as split from his Western, and particularly

\footnotetext{
28 Madeleine Herren, Martin Rüesch and Christiane Sibille, Transcultural History: Theories, Methods, Sources (Springer-Verlag Berlin Heidelberg, 2012).

29 Herren, Rüesch and Sibille, Transcultural History, 47.
} 
Dutch, background. Examining his activities and writings on Islam and Hajj, the chapter exposes Van der Hoog as an "in-between being" who tried to define his new religious belonging as trans-cultural mixture and hybridity that went beyond his original religious and cultural boundaries. His account reveals the experience of a European adventurer in search of new spiritual experiences in the Hajj. In chapter eight Adam Mestyan pinpoints the Hajj narrative of Gyula or Julius Germanus (1884-1979), a Muslim Hungarian Orientalist and a contemporary to Van der Hoog. By using Germanus' travels to the Hijāz and hitherto unstudied documents in Hungarian, Arabic, and English, the chapter shows how the Hajj functions as cultural capital even in the age of mass travel. Germanus attained state recognition by claiming knowledge as a pilgrim of scholarship. Having represented himself as a cultural bridge between the Middle East and Eastern Europe, Germanus tried to instrumentalize his Hajj and connections with the Saudi officials for several goals: to improve his Arabic, to build a personal network which later was useful for cultural diplomacy, and to boost his popularity in Hungary.

The Hajj was affected by World War II and started to take another shape in its relations with Europe in the decolonization era. The emergence of flight itineraries gradually replaced long sea trips, and new Hajj business was created. ${ }^{30}$ The last chapter chronologically ends the age of empires and European colonial ties with Hajj by addressing a historical chapter from Southern Europe, specifically the Spanish involvement in the Moroccan Hajj in Franco's time after World War II. Within the context of the Spanish policy towards Islam, Josep Lluís Mateo Dieste analyses a report by a Spanish colonial officer about a pilgrimage via air voyage that was arranged by the Spanish authorities in 1949 for a group of Moroccan notables. Throughout the 193os the Hajj was a propaganda tool in the hands of the Spanish authorities, especially during the Civil War. Sponsored by the colonial office, the chapter shows how much the Spanish political exploitation of the Hajj was bold in many ways. The trip itself in the last year of European colonization to the Muslim world brings evidence of forms of differentiation exerted by the new nation-states or the colonial powers. Josep Lluís Mateo Dieste remarkably concludes that the Hajj was a vibrant example of entanglement in its ritualising of the Spanish colonial policy and its serving a dual role of Spanish political ceremony and propaganda.

$30 \quad$ Michael B. Miller, "Pilgrims' Progress: The Business of the Hajj," Past and Present 191 (2006): 189-228. 